\title{
A rare association: Ileal duplication cyst, intestinal diverticula and Meckel's Diverticulum
}

\section{Ender bir birliktelik: İleal duplikasyon kisti, intestinal divertikül ve Meckel Divertikülü}

\author{
Mehmet CAN ${ }^{1}$, Ali SAYAN ${ }^{2}$, Ümit BAYOL ${ }^{3}$ \\ ${ }^{I}$ Muş Devlet Hastanesi Cocuk Cerrahisi Kliniği, Muş \\ ${ }^{2}$ Tepecik Ĕgitim ve Araştırma Hastanesi Çocuk Cerrahisi Kliniği, İzmir \\ ${ }^{3}$ Tepecik Ĕgitim ve Araştırma Hastanesi Tibbi Patoloji Kliniği, İzmir
}

\begin{abstract}
Meckel's diverticulum which is a remnant of omphalomesenteric canal is one of the most common surgical pathologies. But they are rarely seen in association with intestinal duplication cysts defined as split notocord anomalies. We present a unique case of a 6 year- old boy referred with acute abdomen clinic and demonstrated combination of Meckel's diverticulum, intestinal diverticula and intestinal duplication cyst as detected during laparotomy. He had an uneventful recovery after we performed ileal resection and anastomosis. It should be considered the rare causes of intestinal obstruction In patients who consulted to the clinics with long-lasting intermittent abdominal pain these rare causes of intestinal obstruction should be kept in mind.
\end{abstract}

Key words: Meckel's Diverticulum, intestinal duplication

$\ddot{\mathbf{O Z Z}}$

Omfalomezenterik kanalın bir kalıntısı olan Meckel Divertikülü en sık görülen cerrahi patolojilerden birisidir. Fakat ender olarak split notocord anomalilerinden biri olan intestinal duplikasyon kistleriyle birlikte görülürler. Bu makalemizde ender görülen bir olguyu; akut batın kliniği ile başvuran ve laparotomide Meckel Divertikülü, intestinal divertikül ve intestinal duplikasyon kisti birlikteliği saptanan 6 yaşında erkek bir hastayı sunuyoruz. Hastamız ileal rezeksiyon anastomoz yapıldıktan sonra sorunsuz iyileşmiştir. Uzun zamandır devam eden aralıklı karın ağrısı yakınması ile kliniğe başvuran hastalarda intestinal obstrüksiyonun bu gibi ender nedenleri de akla getirilmelidir.

Alındığı tarih: 05.08.2015

Kabul tarihi: 16.01 .2016

Yazışma adresi: Uzm. Dr. Mehmet Can, Erzene Mah. 119/2 Sok. No 4/2 Evka 3, Bornova / İzmir e-mail: mcan267@yandex.com

Anahtar kelimeler: Meckel Divertikülü, intestinal duplikasyon

\section{INTRODUCTION}

Meckel's diverticulum is the most common congenital anomaly of the gastrointestinal tract which exists in the $2 \%$ of all population ${ }^{(1)}$. Intestinal duplications are less common $(0.2 \%)$ and exist in three forms , as tubular, cystic and intramural duplications

(2). Both the Meckel's diverticulum and the duplications are two times more common in boys than girls ${ }^{(2)}$. Both have a well developed coat of smooth muscle but while the Meckel's diverticulum occurs on the antimesenteric border, intestinal duplications occur on the mesenteric border ${ }^{(2)}$. In our case we demonstrated a Meckel's diverticulum with a cystic intestinal duplication and an ileal diverticulum located on terminal ileum in a 6 year- old boy.

\section{CASE REPORT}

A 6 year- old male presented with a history of 
intermittent abdominal pain for two months which worsened and accompanied by bilious vomiting for the last 24 hours. Vital parameters were normal. Findings of mild dehydration was detected on physical examination together with abdominal distention and tenderness. Bilateral undescended testis (both palpated in inguinal canal) was determined and the rectum was empty in rectal examination.

There was no pathologic findings except leucocytosis $\left(14500 / \mathrm{mm}^{3}\right)$ and minimally increased CRP $(6.0$ $\mathrm{mg} / \mathrm{dL})$. Air-fluid levels were observed on plain

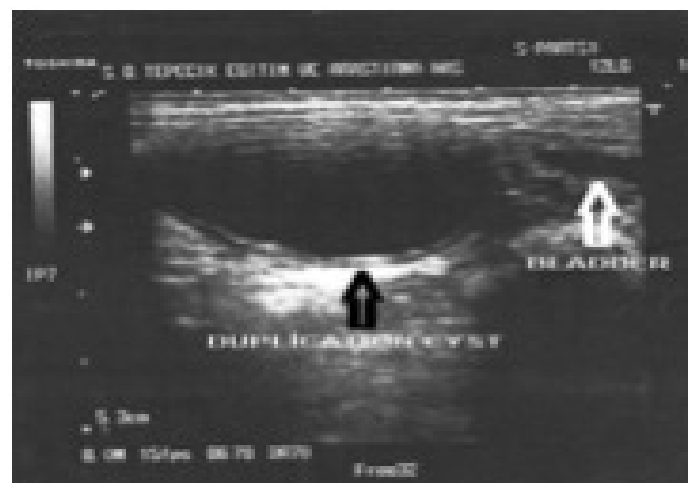

Figure 1. Cystic mass next to the bladder in USG.

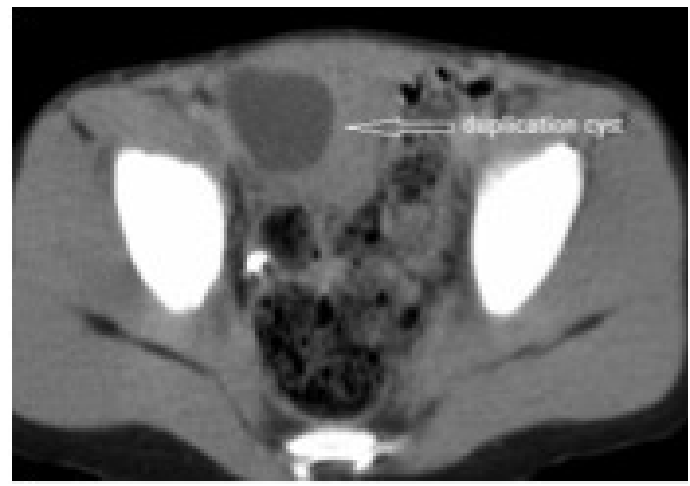

Figure 2. Cystic mass in CT.

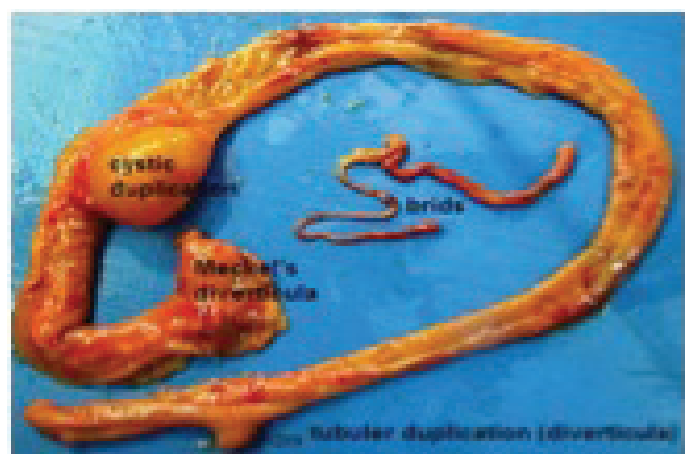

Figure 3. Resected part of ileum with brids. abdominal radiograms (Figure 1). On ultrasonograms a cystic mass $3.5 \times 2.5 \mathrm{~cm}$. in size was observed at the right lower quadrant (Figure 2). After NG decompression and IV fluid resuscitation, the clinic manifestations of ileus ameliorated. Abdominal CT confirmed that the cystic mass was $4 \times 3 \mathrm{~cm}$ in size at the same location (Figure 3). The tumor markers were normal.

At elective laparotomy we demonstrated the presence of a $1 \mathrm{~cm}$ long diverticula (tubular intestinal duplication) located on the mesenteric border of intestine and $5 \mathrm{~cm}$. proximal to the ileocaecal valve. Another cystic intestinal duplication of $3 \mathrm{~cm}$ in diameter was located $15 \mathrm{~cm}$ proximally from the first and the Meckel's diverticulum was located $5 \mathrm{~cm}$ proximally from the second. A bride which extended from the apex of Meckel's to intestinal loops was firstly excised then after the resection of $30 \mathrm{~cm}$ ileal segment including the three pathologies, ileoilealanasthomosis was performed. The patient had an uneventful recovery and fed on the fifth day after the operation.

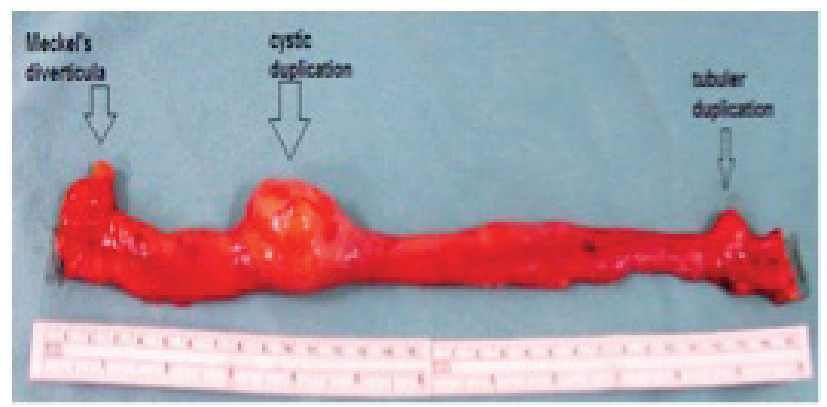

Figure 4. Distal $30 \mathrm{~cm}$ of terminal ileum including the three pathologies.

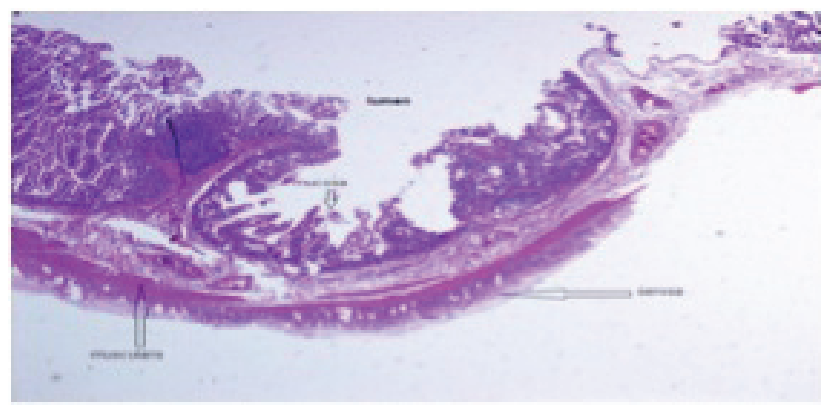

Figure 5. Tubular duplication coated with normal intestina Imucosa (Hematoxylin and Eosin stain, 40x). 
Histopathological findings

The excised bowel segments were fixed in $10 \%$ formaldehide solution, and several samples were taken from each lesion, and these samples were embedded in parafin and serially cut into $5 \mu \mathrm{m}$-thick sections. After deparaffinization sections were dyed with hematoxylin and eosin stain. Intestinal mucosa lining Meckel's diverticulum was seen. Second pathology was intestinal partial doubling of the bowel segment with organized smooth muscle in the wall (Figure 5). Third pathology was cystic dilatation covered with intestinal mucosa and organized smooth muscle in the wall, i.e. ileal duplication cyst (Figure $6)$.

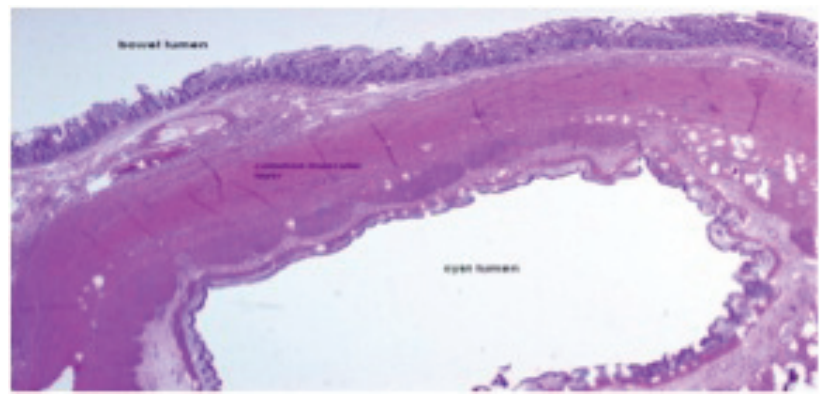

Figure 6. Cystic duplication and bowel with common muscular layer (Hematoxylin and Eosin stain, 40x).

\section{DISCUSSION}

Meckel's diverticulum which is an omphalomesenteric duct remnant is the most common congenital malformation of intestine. Because most of the people are asymptomatic, it's difficult to determine the true incidence but most studies suggest that it occurs in about $2 \%$ of the population. Though it's located usually $40-100 \mathrm{~cm}$ proximally to the ileocaecal valve, it can occur anywhere between the Treitz ligament and ileocaecal valve ${ }^{(3)}$. The most common ectopic tissues in Meckel's diverticulum are gastric and pancreatic tissues. Both the Meckel's diverticulum itself and it's complications like bleeding, diverticulitis, perforation and intestinal obstruction are more common in male patients. Except the bleeding due to ectopic tissue and the invagination due to lead point effect, all other complications like diverticulitis, perforation and intestinal obstruction are secondary to intestinal twisting around the tract ${ }^{(5,6)}$.

Gastrointestinal duplications are less common (1/4500 birth). Though many different terms were used before to determine this patologies like giant diverticula, inclusion cyst, enteric cyst, enterogenous cyst, reduplication, ileum duplex, unusual Meckel's diverticulum and accessory enteric formation, today we know all they are the same patology ${ }^{(7)}$. Usually they are tightly attached to the nearby digestive duct and located on the mesenteric border between the mesenteric leaves. They have a well-developed coat of smooth muscle. Though the tissue lining the inner aspect is the same with the native tissue it can belong anywhere in the gastrointestinal tract. Most duplications are diagnosed by age 2 and the most common is the cystic type among other types (cystic, tubular, intramural determined).

Multiple duplications are observed in 5-10\% of the patients ${ }^{(8)}$. Though it is located anywhere along the gastrointestinal tract from mouth to anus, the most common location is terminal ileum. It could contain various heterotopic tissues like gastric (most common) or pancreatic tissues, squamous or cilliated epithelium, lung tissue, cartilage, striated muscle or colonic mucosa. The clinical presentation varies according to location and the presence of ectopic tissue as symptomatic/asymptomatic mass, rectal bleeding, intestinal obstruction or abdominal pain only. Though several theories have been suggested on the embriology of these lesions like uterovascular accident, failure of recanalization or retained embriologic diverticulum, there is a prevalent consensus on the split notocord theory. There is additional anomalies in $25 \%$ of the patients that are usually vertebral anomalies like hydrocephalus, spina bifida and myelomeningocele which further support the theory. Cleft palate, cardiac anomalies, lung and diafragma malformations, oesophagial atresia, duodenal atresia, anorectal malformations, intestinal rotation anomalies, omphalocelle, extrophia vesicale and genital malformations can also be observed ${ }^{(8)}$. Although rarely, 
these anomalies have also been reported in association with Meckel's diverticulum $(4,11,12)$. Long duplications of the intestinal tract are treated by complex methods like internal drainage or mucosal peeling but resection and anastomosis are the best alternatives for short segments.

Our case is unusual due to the presence of both tubular and cystic duplications with Meckel's diverticulum in terminal ileal segment of $30 \mathrm{~cm}$. Though this patologies manifest themselves up to 2 years after onset of the disease in most patients, it was asymptomatic up to 6 years in our case. The bilaterally undescended testis is also an example for the rare condition that can be observed with intestinal duplications. It was possible to do the operation in elective conditions because of the response to the supportive treatment in this patient but in cases requiring emergency laparotomy considering the Meckel's diverticulum and brides caused the table, the additional anomalies may be missed????. It was a chance that all the patologies were within an intestinal segment of $30 \mathrm{~cm}$. Because a short intestinal segment was affected, resection was performed including the three anomalies. The anomalies located away from each other may require separate resectionanasthomosis and even if the Meckel's diverticulum which doesn't contain ectopic tissue and responsible for the clinical symptoms may be left in place. In our case Meckel's diverticulum was also resected because of the presence of brides. We did not perform appendectomy because there was no pathology at appendix and caecum.

As a result both cystic and tubuler duplications and a Meckel's diverticulum were found during the laparotomy of a child suffering from intermittent abdominal pain for two months. In such cases even if the pathology causing the clinical symptoms is Meckel's diverticulum, intestinal duplication that can lead to bleeding, obstruction, infection and even malignant transformation should be resected. If the Meckel's diverticulum is not the cause of the clinical symptoms, then the decision of excision should be depend on the distance between the lesions on the intestinal segment that will be affected. In addition we think that all the gastrointestinal tract should be overwieved for additional anomalies during laparotomy.

\section{REFERENCES}

1. Anyfantakis D, Kastanakis M. Papadomichelakis. Perforation of Meckel's Diverticulum by a Wood Splinter in a 4-YearOld Child: A Case Report. Journal of Medicine and Life 2013;6:195-197.

2. Başaklar AC. Bebek ve Çocukların Cerrahi ve Ürolojik Hastalıkları. 2006;1:823.

3. Mc.Svain Gr, Anderson MC. Meckel Diverticulum of the Proksimal Jejunum. Arch. Surg 1979;114:212. http://dx.doi.org/10.1001/archsurg.1979.01370260102018

4. Milbrandt K, Sigalet D. Intussusception Associated With a Meckel's Diverticulum and Duplication Cyst. Journal of Pediatric Surgery 2008;43:E21-E23. http://dx.doi.org/10.1016/j.jpedsurg.2008.09.005

5. Soltero MJ, Bill AH. The Natural History of Meckel's Diverticulum and its Relation to Incidental Removal: A Study of 202 Cases of Diseased Meckel's Diverticulum Foundin King County, Washington, Over a Fifteen-Year Period. Am J Surg 1976;132:168-173. http://dx.doi.org/10.1016/0002-9610(76)90043-X

6. Vane DW,West KW, Grosfeld JL. Vitelline Duct Anomalies: Experience with 217 Childhood Cases. Arch Surg 1987; 122:542-547. http://dx.doi.org/10.1001/archsurg.1987.01400170048007

7. Ramakrishna HK. Intestinal Duplication. Indian J Surg 2008;70:270-273. http://dx.doi.org/10.1007/s12262-008-0082-0

8. Bond SJ, Groff DB. 'Gastrointestinal Duplications' in O'Neill JA, Rowe MI, Grosfeld JL et al. Pediatric Surgery, St. Louis, Mosby, 1998; pp:1257-1667.

9. Mc. Letchie NG, Purves KJ, Saunders RL. The Genesis of Gastric and Certain Intestinal Diverticula and Enterogenous Cysts. Surg Gynecol Obstet 1954;99:135.

10. Heller K, Waag HK, Beyersdorf F. Intestinal DuplicationsIntestinal Diverticula-Segmental Dilatation Of IIntestine; A Common Genetic Complex. Pediatr Surg Int 1989;4:249253. http://dx.doi.org/10.1007/BF00177493

11. Bishop HC, Koop CE. Surgical Management of Duplications of Alimentary Tract. Am J Surg 1964;107:434-442. http://dx.doi.org/10.1016/0002-9610(64)90210-7

12. Carachi R. The Split Notocord Syndrome: A Case Report on A mixed Spinal Enterogenous Cyist in a Child With Spina Bifida Cystica. Z Kinderchir 1982;35:32-34. 